NBER WORKING PAPER SERIES

MONETARY POLICY IN THE LARGE OPEN ECONOMY

Michael R. Darby

Working Paper No. 1127

NATIONAL BUREAU OF ECONOMIC RESEARCH

1050 Massachusetts Avenue

Cambridge MA 02138

May 1983

The research reported here is part of the NBER's research program in International Studies and project in Productivity in the World Economy. Any opinions expressed are those of the author and not those of the National Bureau of Economic Research. 
Monetary Policy in the Large Open Economy

\section{$\underline{\text { ABSTRACT }}$}

This paper discusses recent evidence on the imperfect international substitutability of goods and assets and the implications for conduct of monetary policy in a major industrial country. A simple model is developed for analysis of the simultaneous determination of money growth and the balance of payments under pegged exchange rates. Parallels are drawn to the importance of expected depreciation in determination of floating exchange rates. An assessment is made of the extent to which a central bank can simultaneously pursue both exchange rate and money supply goals through sterilized intervention. The paper concludes with the role of saving rate differences in determining nonzero equilibrium trade balances.

Michael R. Darby Department of Economics University of California, Los Angeles Los Angeles, California 90024

(213) $825-3343$ 
For the Bank of Japan's Centenary

Conference on "Monetary Policy in Our

Time," Tokyo, Japan, June 22-24, 1983

D. 3: Apr11 16, 1983

\title{
MONETARY POLICY IN THE LARGE OPEN ECONOMY
}

\author{
Michael R. Darby* \\ University of California, Los Angeles \\ National Bureau of Economic Research
}

Economists are fond of downward sloping demand curves and upward sloping supply curves except when describing a nation's international economic

relations. In that case these curves are generally assumed to be elther horizontal or vertical as required to describe a perfectly open or perfectly closed economy. The reason for this exceptional behavior on the part of economists is easy to see: Simple models can be used in either extreme case, but the analysis becomes rather complex in the intermediate case in which economies are open but far from perfectly so. ${ }^{1}$ This paper will first report on recent empirical research that rather conclusively rejects either extreme model for the major (noncommunist) industrial nations. The implications of imperfect openness for their centrai banks' monetary policies will then be

* The author acknowledges helpful comments from Sebastian Edwards, Maxwell Fry, James Lothian, Maurlce Obstfeld, and members of the UCLA Workshop in Monetary Economlcs. The research reported here was supported partially by the National Sclence Foundation and is part of the NBER's research program in International Studies. Any opinions expressed are those of the author and not those of the National Bureau of Economic Research.

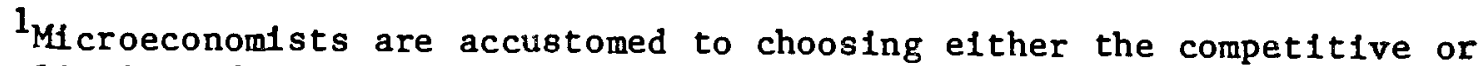
monopolistic model according to the problem at hand; they thus generally avold the numbing complexity and inconclusiveness of the varlous oligopolistic models. Unfortunately, such a cholce between the extreme macroeconomic models would preclude - as I attempt to demonstrate below - serlous analysis of monetary policy in the major Industrial countries. Fortunately, the complexity of the intermediate model appears less severe than in the case of ollgopoly. 
analyzed. Finally the role of capital flows in determining the long-run equilibrium values of the balance of trade and real exchange rate is discussed. 


\section{Goods and Assets as Imperfect Substitutes Internationally}

E1ther or both of two major assumptions have been used to characterize perfectly open economies: goods are perfect substitutes internationally or securities are perfect substitutes internationally. This section reports on recent empirical work which decisively rejects both hypotheses. Most of the work summarized here was done as part of the NBER's International Transmission Profect and will be reported by my collaborators and self in Darby, Lothian, Gandolf1, Schwartz, and Stockman (1983).

\section{Goods Substitution}

The "global monetarists" like Laffer (1975) argued that internationally traded goods are, for all practlcal purposes, perfect substitutes across borders with prices rigidly inked by arbitrage. ${ }^{2}$ Factor competition between tradable and nontradable goods was used to extend this arbitrage relation to the "law of one price level" which held that purchasing power parity continuously attains - not just in the long-run as in the Humean tradition. ${ }^{3}$ Previous empirical research, such as Isard (1977), Kravis and Lipsey (1977, 1978), and Richardson (1978), has concluded that goods are substitutable internationally, but far from perfectly so.

2The term in quotation marks was introduced in Whitman's (1975) survey article. In the relevant sense, price arbitrage requires that domestic prices be strictly proportional (not necessarily equal) to the exchange rate converted forelgn prices. This implicitly assumes proportional shipping costs and tariffs and that each good is always shipped in the same direction.

3 Fausten (1979) persuasively distinguished the Humean tradition from the law of one price level. 
The International Transmission Project results support that conclusion. In a medium-scale simultaneous equation model of Canada, France, Germany, Italy, Japan, the Netherlands, the United Kingdom, and the United States estimated for 1957-1976, the relative-price effects on the balance of trade implicit in export and 1mport equations are small in the initial quarter although they do increase over time. ${ }^{4}$ In bivariate Granger causality tests between domestic and forelgn inflation for the same elght countries, lagged forelgn Inflation was generally insignificant. Furthermore, there was no evidence that price changes led money changes in nonreserve countries under pegged exchange rates as suggested by analyses based on the law of one price leve1.5 Only weak and far from universal forelgn-price effects were found in reduced-form price equations estimated for the same elght countries. 6 Thus our results confirm the previous conclusion: Goods are imperfect substitutes internationally.

\section{Asset Substitution}

The central bank's monetary pollcy may affect substantially and Immediately the balance of payments through asset flows even if the balance of trade inftially responds only weakly. Indeed in view of the previous empirical rejection of perfect good substitution, perfect asset substitution

${ }^{4}$ Darby, Lothlan, et al. (1983, Chapters 5 and 6 by Daṛby and Stockman).

${ }^{5}$ Darby, Lothian, et al. (1983, Chapter 4 by Cassese and Lothian). The tests were run for periods ending 1971, 1973, and 1976.

${ }^{6}$ Darby, Lothian, et al. (1983, Chapter 14 by Gandolfi and Lothian). 
has become the usual defining characteristic of a perfectly open economy. ${ }^{7}$ In this context, perfect asset substitution means that the domestic interest rate Is equal to the foreign interest rate minus the expected appreciation (per annum) of the domestic currency over the term to maturity of the securities. In contrast, 1mperfect asset substitutability 1mplies that there is a risk premium between the two interest rates which varies with the relative stocks of domestic and forelgn assets and which hence responds to international capital flows. Thus, lower domestic interest rates could induce finite capital outflows which raise the risk premium on forelgn assets enough that no further flows are induced by the ylelds on domestic securities which are lower than the expected yields on foreign securities. 8

The International Transmission Project approached this question in a number of ways. Cassese and Lothian found that lagged as we11 as current American interest rates had significant effects on the other seven countries' interest rates during the pegged perlod; indeed generally the lagged effects were more important quantitatively in contradiction to perfect short-run asset substitution. 9 In the structural model the estimated interest-rate effects on capital flows were small; simulations confirmed that monetary polfcy changes

${ }^{7}$ Asset substitution is used here to refer to various national interestbearing securities; there is little if any evidence for the large industrial nations of direct substitution in demand of the national moneys ("currency substitution"). See also Cuddington (1983).

${ }^{8}$ Imperfect asset substitution results in the portfollo-balance models pioneered by Branson $(1968,1970)$ and discussed at length below.

${ }^{9}$ Darby, Lothian, et al. (1983, Chapter 4 by Cassese and Lothian). 
did not Induce very large short-run balance of payments effects under pegged exchange rates. 10

An Indirect approach provided strong evidence agalnst perfect asset substitution for the seven nonreserve countries under pegged exchange rates. As demonstrated in Section II below, this condition is sufficient to render their domestic monetary policy Impotent under pegged exchange rates. It was shown that domestic policy goals were in fact significant determinants of these countries' money supply growth. 11 Daniel Laskar estimated the fraction of a shift in the money supply reaction function which would be reflected in the domestic money supply given the Induced capital flows and the sterilization behavior of the central bank. For all seven nonreserve countries under pegged exchange rates this fraction significantly exceeded 0 but did not significantiy differ from 1.12 Thus the actual exerctse of shortrun monetary control during the Bretton Woods era is inconsistent with the usefulness of the perfect asset substitution hypothesis.

Moreover, the International Transmission Project's strong results are consistent with the best recent empirical work reported in the ilterature. Geweke and Felge (1979), Hansen and Hodrick (1980, 1982), B1lson (1981), and Cumby and obstfeld $(1981,1983)$, for example, all reject the hypothesis that the forward exchange rate is an unbiased predictor of the future spot rate as 10 Darby, Lothlan, et al. (1983, Chapters 5 and 6 by Darby and Stockman,
Chapter 7 by Darby).

${ }^{11}$ Darby, Lothian, et al. (1983, Chapter 10 by Darby).

${ }^{12}$ Darby, Lothian, et al. (Chapter 11 by Laskar). 
it would be under perfect asset substitution. 13 Dooley and Isard (1979) and Frankel (1982) have in contrast reported an inability to relate risk premiums to outstanding bond supplies, but these results may well be explained by the rather low power of their tests. 14 Furthermore, these tests all examine the floating period in which assets should be relatively better substitutes than under pegged rates when capital controls - and the risk of their imposition - were more significant factors and international financial markets were less we11 developed. The new evidence in Darby, Lothian, et al. (1983) appears virtually to eliminate perfect asset substitution as a viable hypothesis.

${ }^{13}$ Covered interest arbitrage imposes the condition that the domestic and foreign interest rates will differ only by the discount or premium implicit in the forward rate. Under 1mperfect asset substitution, the forward rate will differ from the expected future spot rate by a risk premium that varies as capital flows change outstanding holdings of bonds. This risk premium is normally related to the role of exchange rate risk in the modern theory of flnance (Solnik 1973), but Dooley and Isard (1980) argue that political risk of capital controls varies with the stock of outstanding debt. This factor may well be the more important.

14 Michael Melvin in Chapter 13 of Darby, Lothian, et al. (1983) was rather more successful in applying Solnik's (1973) international asset pricing model to explaining international capital flows. 


\section{Independent Monetary Pollcy under Pegged Exchange Rates}

The fact that for large Industrial countries such as Japan or Germany nelther goods nor assets are perfect substitutes internationally implies that changes in the central bank's reserves w1ll permit it - within limits discussed below - to pursue simultaneously monetary and exchange-rate goals. Indeed, even under pegged exchange rates independent monetary policy 1s, to an extent, feasible in the short run. Although the floating-rate regime is of most interest currently, it is helpful to first consider the simpler case of pegged exchange rates. 15

In Darby, Lothian, et al. (1983, Chapter 10), I propose a simple graphical device for analyzing the simultaneous determination of the balance of payments and nominal money supply in a large, Imperfectly open economy maintalning a pegged exchange rate. The model combines the central bank's reaction function with the semi-reduced form equation describing the economic environment within which the bank operates.

The central bank's reaction function provides a formal statement of the behavior of the monetary authorities working through the banking system. It may be written compactly as

$$
\Delta \log M=\alpha \frac{B}{B}+X \beta+u
$$

${ }^{15}$ It could well be argued that a number of major European nations are de facto pursuing pegged exchange rates with the German mark which in turn floats relative to the U.S. dollar, the yen, and other major currencies. The model would apply directly to these countries. 
where $M$ is the nominal money supply, $B / H$ is the current period balance of payments surplus divided (or scaled) by nominal base (high-powered) money, $\mathrm{X}$ is a vector of all other varlables which systematically affect the central bank's behavior, and $u$ is a random disturbance. Note particularly that lagged values of $B / H$ or scaled reserves may appear in $X$. Here we are concerned with monetary Independence within the short perfod, but the short-period curves may well shift in the next period in response to what happens this period. The parameter $\alpha$ measures the extent to whlch the central bank sterillzes reserve flows with1n the period: If $\alpha$ is 1 , there is no sterilization while if $\alpha$ is 0 sterilization is complete. 16 In other words, $\alpha$ represents the fraction of the current balance of payments which the central bank allows to be reflected In base money. 17

Although a complete structural model of the economy will not be produced here, ${ }^{18}$ it 1 s useful to define partty money growth $(\Delta \log M)_{p}$ as that change

${ }^{16}$ Independent estimates reported In Chapters 6 and 11 of Darby, Lothian, et al. (1983) places $\alpha$ between 0 and 0.2 or 0.3 for all seven nonreserve countrles; only for Germany and perhaps Japan and the Netherlands does $\alpha$ slgnificantly exceed 0 for quarterly observations. Generally lagged adjustments are found to be substantial, however. Examples of other authors who report evidence of substantlal short-run sterilization are Herring and Marston (1977), Hill1ard (1979), Connolly and Taylor (1979), and Obstfeld $(1980,1982 \mathrm{~b})$. Laney and Willett (1982) present a tabular survey of est1mated sterilization coefficlents reported through 1980.

17 Some authors prefer to cast the central bank's reaction function in terms of the scaled change in domestic credit:

$$
\frac{\Delta D}{H}=(\alpha-1) \frac{B}{H}+X_{\beta}+u
$$

However, In the presence of even partlal sterilization $(\alpha<1)$ domestic credit has no substantive role in elther theoretical or emplrical analysis and is accordingly dropped. Its computation is stralghtforward for the interested reader. Note that if $\alpha=1$, scaled growth in domestic credit is $X \beta+u$.

${ }^{18}$ See, however, Darby, Loth1an, et al. (1983, Chapters 5 and 6) for Stockman's and my attempt to do so. 
consistent with substituting in the money demand equation the exchange-rate converted forelgn price level and forelgn interest rate: 19

$$
(\Delta \log M)_{p}=Z \delta+\varepsilon
$$

Money. growth faster than $(\Delta \log M)_{p}$ will be associated with domestic interest rates lower and prices higher than their international parity values. Lower interest rates will induce capital outflows while higher prices will reduce the trade balance; thus money growth in excess of $(\Delta \log M)_{p}$ w1ll reduce the balance of payments surplus. Formally, we can write the semi-reduced form for the scaled balance of payments as

$$
\frac{B}{\mathrm{H}}=\theta(\Delta \log M-Z \delta-\varepsilon)+S \lambda
$$

where $S$ is a vector of all other factors affecting the balance of payments such as those contained in the trade supply and demand equations. Specification of $S$ is not of concern for the current analysis. Our primary concern is the function $\theta$ which determines the derivative of the scaled balance of payments with respect to money supply growth.

${ }^{19} \mathrm{~A}$ minor complication arises if the nominal money supply has a contemporaneous effect on real income. A considerable complication of the analysis arises if we consider the following (second-order) effect which arises when assets are 1mperfect substitutes: In that case a change in central bank reserve holdings moves the equilibrium domestic interest rate relative to the forelgn interest rate. Then monetary pollcy could affect the money stock and output without affecting prices. This point, which is due to Maurice Obstfeld, suggests a way in whlch monetary policy would not be entirely impotent (given 1mperfect asset substitution) even if goods were perfect substitues. I assume here that the money demand effects of the balance of payments through both the interest rate and output channels are negligible in the short period being analyzed. 
The scaled balance of payments is, by the accounting identities, the difference between the scaled trade balance $(T / H)$ and the scaled net private capital outflows $(\mathrm{C} / \mathrm{H}):^{20}$

$$
\frac{B}{\mathrm{H}} \equiv \frac{\mathrm{T}}{\mathrm{H}}-\frac{\mathrm{C}}{\mathrm{H}}
$$

Scaled net private capital outflows will be a function of the current covered Interest differential (adjusted for expected exchange rate changes) and other variables which may be taken as given for the current period: 21

$$
\frac{C}{H}=f\left(R-\rho-R^{F}\right)
$$

where $\rho$ is the expected depreciation of the exchange rate $(\rho<0$ implies an expected apprectation), $R^{F}$ is the given forelgn interest rate, and so $f^{\prime}$ is negative. We find $\theta^{\prime}$ by differentiating equation (4):

${ }^{20}$ The variable $\mathrm{C} / \mathrm{H}$ is here defined as minus the net cash flow from international investment -- that is, as net foreign investment less net securities income. However, we neglect within the short perlod the second order effect of lower domestic interest rates increasing net securities income and hence lowering $\mathrm{C} / \mathrm{B}$; portfollo adjustments are assumed to overwhelm this effect.

${ }^{21}$ Among these other variables is, of course, the lagged covered interest differential since changes in the differential will cause portfollo revisions and hence net capital flows. These other variables are predetermined within the period and so implicit in the function $f()$. As discussed in footnote 19, the balance of payments w1Il have a direct effect on the partiy value of the domestic interest rate undef imperfect asset substitution so that we might prefer $C / B=f\left(R+Y[B / H]-p-R^{F}\right)$. However, this merely requires substitution of $[(d \rho / d(B / B))-\gamma]$ for $d \rho / d(B / B)$ in equation ( 7$)$. Since elther term is definitely negative, none of the qualitative results are affected whether we think of the balance-of-payments effect on domestic interest rates as reflecting only an expected depreclation factor or also a portfollo-balance factor. 


$$
\theta^{\prime} \equiv \frac{d(B / H)}{d \Delta \log M}=\frac{d(T / H)}{d \Delta \log M}-f^{\prime} \frac{d R}{d \Delta \log M}+f^{\prime} \frac{d \rho}{d(B / H)} \frac{d(B / H)}{d \Delta \log M}
$$

$$
\theta^{\prime}=\frac{1}{1-f^{\prime} \frac{d \rho}{d(B / H)}}\left(\frac{d(T / H)}{d \Delta \log M}-f^{\prime} \frac{d R}{d \Delta \log M}\right)
$$

The multiplier $1 /\left(1-f^{\prime} \frac{d \rho}{d(B / H)}\right)$ states that if the expected depreciation $\rho$ responds to the size of the balance of payments (as an Indicator of the probability and size of a revaluation), then the direct trade and capital flow effects w111 be relnforced by induced "speculative" capital flows. 22 These induced speculative capital flows will be overwhelming unless

$$
f^{\prime} \frac{d \rho}{d(B / H)}<1
$$

Thus expected depreciation, which plays such an important role in recent analyses of floating exchange rates, is potentially 1mportant under pegged exchange rates also.

Solving equation (3) for money growth ylelds

$$
\Delta \log M=\phi\left(\frac{B}{H}-S \lambda\right)+Z \delta+\varepsilon
$$

where $\phi$ is the Inverse of the function $\theta .23$ That is, increases in the balance

${ }^{22}$ Given the (predetermined) lagged value of scaled reserves, B/H tells us the value of current scaled reserves which B1lson (1979) and Harberger and Edwards (1982) argue is an important Indicator of the probability of devaluation. Bilson also proposes a monetary indicator which can be interpreted as the integral of $\Delta \log M-Z \delta-\varepsilon$; this is subsumed in the total derivative $d \rho / d(B / H)$.

${ }^{23}$ If goods are perfect substitutes internationally (and [d $\log P / d(\Delta \log M)]>0)$ or if assets are (and $[d \log R / d(\Delta \log M)]<0$ ) or both, then $\theta$ would reduce to a constant coefficlent - so that $\phi$ would be the constant 0 and $\Delta \log M=\mathrm{Z} \delta+\varepsilon$ which 1 s the standard "monetary approach" result. 
of payments relative to its parity value $S \lambda$ are associated with decreases in money growth relative to 1ts parity value. Figure 1 plots equations ( 1 ) and (9) on the same graph to 1llustrate the simultaneous determination of equilibrium money growth $(\Delta \log M)^{e q}$ and the balance of payments $(B / H)^{e q}$. The equation (1) line would be vertical if the central bank completely sterilized the contemporaneous balance of payments; 1ts positive slope here indicates partial sterilization 1s practiced. The (9) line would be vertical if condition (8) was not met or under perfect 1nternational substitutability of goods or assets; ${ }^{24}$ the 11 ne is drawn here as negatively sloping in the relevant region. 25 Unless the two lines happened to colncide, there would be no equilibrium if both IInes were vertical. The intersection of the (1) and (9) IInes gives the short-period equilibrium values of the scaled balance of payments and money growth. 26

Suppose that economic conditions characterized by $\mathrm{x}_{1}$ include higher domestic unemployment than those in $\mathrm{X}_{0}$ and that this increases the money growth desired by the central bank for any given value of the balance of payments $\left(\mathrm{X}_{1} \beta>\mathrm{X}_{0} \beta\right)$. As 1llustrated in Figure 2, this shift in domest1c policy goals Induces an Increase in money growth and decrease in the balance of payments. The more open is the economy, the steeper w1ll be the downward sloping line which represents the central bank's payments-balance/money-growth tradeoff, and the greater w1ll be the balance of payments effect and the

\section{${ }^{24}$ See note 23 above.}

${ }^{25}$ The multiplier of equation (7) is positive with condition (8) holding while $-\infty<[\mathrm{d}(\mathrm{T} / \mathrm{H}) / \mathrm{d}(\Delta \log \mathrm{M})]\langle 0$ and $\infty\rangle\left[\mathrm{f}^{\prime} \mathrm{dR} / \mathrm{d}(\Delta \log \mathrm{M})\right]>0$ under 1mperfect substitution. Therefore $t^{\prime}\left\langle\theta^{\prime}<0\right.$ which 1mplies $-\infty<\phi^{\prime}<0$.

${ }^{26}$ If this also corresponds to a long-perlod equilibrium, it should be along a line from the origin with slope less than 1. In that case money growth derives from growth in both reserves and domestic credit. 
F IGURE 1

Simultaneous Determination of Balance of Payments and Nominal Money under Pegged Exchange Rates

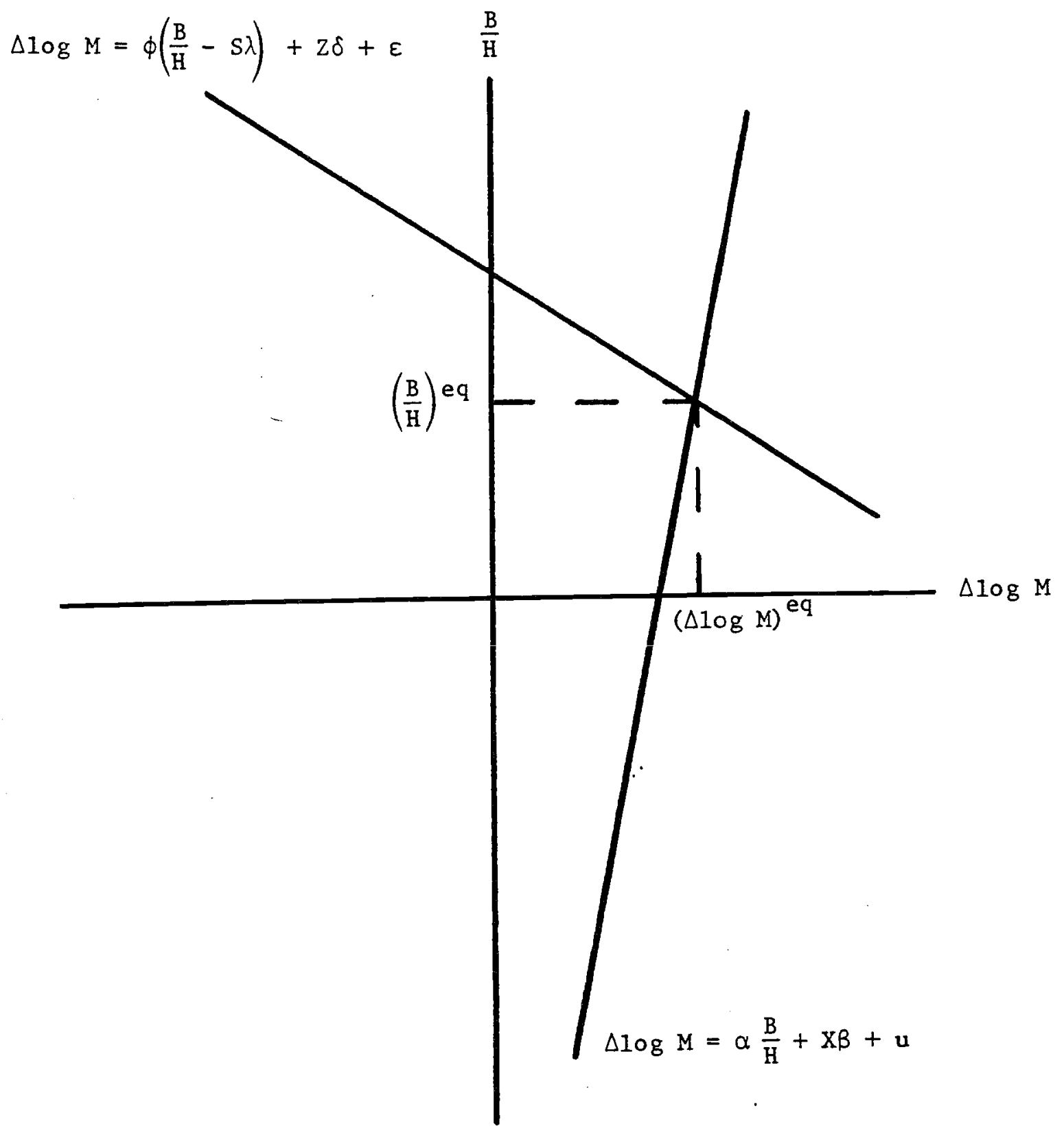




\section{FIGURE 2}

Effect of Shift in Domestic Policy Goals

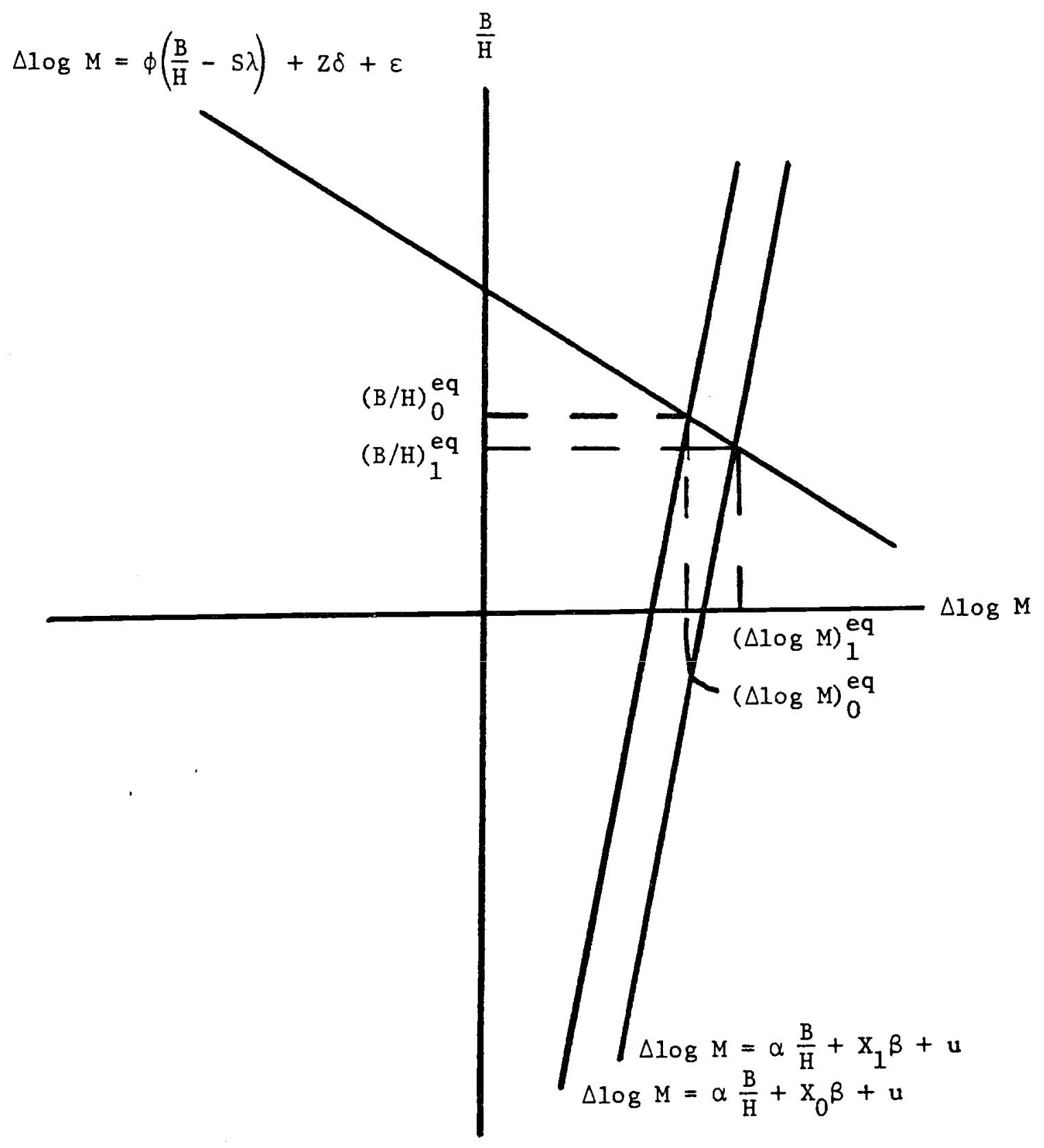


lesser the money growth effect of any given shift in the central bank's reaction function. 27

The graphical analysis did not take account of the possibility that both the probability and the size of a devaluation may increase with the absolute value of $B / H$ or 1 ts deviation from its parity value $S \lambda$. If this is so $d \rho / d(B / H)$ will approach the critical value $1 / f^{\prime}$ for large absolute values of $B / H$ and therefore the tradeoff w111 worsen as in Figure 3.28 This possibility, as well as the implied effects on future tradeoffs, would 11mit the range within which the central bank would choose to operate. The size of this range remains unknown, but the evidence in Darby, Lothian, et al. (1983) suggests that a ten percent deviation of the actual from the parity level of nominal money is near the limit of monetary independence for large open economies which malntaln a pegged exchange rate. Furthermore, this deviation cannot be maintalned indefinitely because of the cumulative effect on reserves of continuing large balance-of-payments deficits or surpluses. Ultimately elther monetary policy or the exchange-rate peg must be adjusted.

27 However, In choosing $\alpha$ and $\beta$ the central bank is aware of the (expected) tradeoff which it faces, so generally alternatively shaped tradeoffs would Induce alternative reaction functions. Lucas's (1976) critique 1mplies that the shape of the tradeoff surface may also depend upon the central bank's cholce of $\alpha$ and $\beta$. Furthermore, a government pursuing a nationalistic monetary policy may offset the balance-of-payments effects of the pollcy by changes $1 \mathrm{n}$, say, comnerclal policy which affect $S \lambda$ so as to shift the (9) line upwards.

${ }^{28}$ This analysis provides a rather simpler explanation of when balance-ofpayments crises occur than that suggested by Krugman (1979.). As the central bank moves money growth further from the parity value, the stability condition (8) is finally violated and speculative capital flows become overwhelming. In the medium scale model reported in Darby, Lothian, et al. (1983), $\mathrm{d} \rho / \mathrm{d}(\mathrm{B} / \mathrm{H})$ does increase in absolute value with $|(B / H)|$, but the stability condition appears to hold except at the time of actual balance-of-payments crises. 


\section{F IGURE 3}

\section{Simultaneous Determination of Balance of Payments and Money Where Potentially Unstable Speculation Limits Monetary Control}

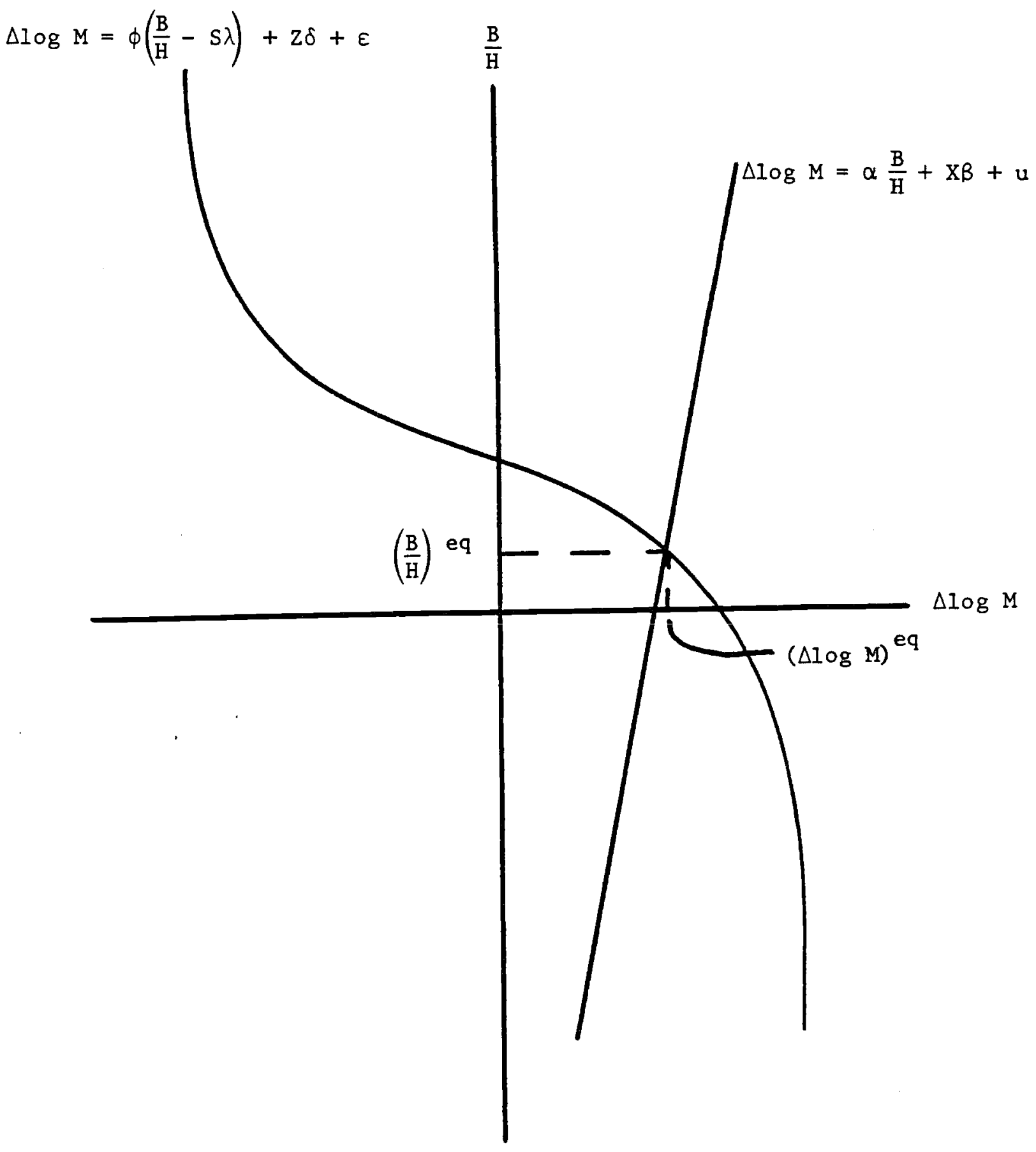


III. Monetary Polfcy, Floating Exchange Rates, and the Trade Balance

The theoretical and empirical analysis of the effects of monetary policy under floating exchange rates has not progressed to the point that neat summary diagrams can be produced to 1llustrate major results. Indeed we seem to know disappointingly little despite the expenditure of much talent and effort. If this section seems maddeningly tentative to the policymaker, it must be recalled that false knowledge is far more dangerous than an awareness of ignorance.

Broadly speaking, economists' prior expectations of the results of widespread floating among major currencies have been confirmed in two major respects, but economists have been surprised in one 1mportant aspect. Generally economists were correct in their expectations of long-run neutrality and enhanced monetary Independence but erred in predictions that exchange rates would gradually move in reflection of relative inflation rates.

The long-run neutrality of the economy with respect to monetary policy is perhaps our most secure result: That is, an increase in the level of money w111 -- In the long run and with other things equal -- be reflected in an equal increase in prices and the nominal exchange rate with no effect on real output or the real exchange rate. ${ }^{29}$ Superneutrality is rather less secure: 30 First, as in any closed economy, higher money growth and hence

${ }^{29}$ The nominal exchange rate is measured as domestic currency units per unit of forelgn currency. The real exchange rate (also known as the purchasing power ratio) is the nominal exchange rate times the ratio of the forelgn to the domestic price level.

${ }^{30}$ Superneutrality implies that the real variables in the economy (e.g., real output and the real exchange rate) are unaffected in long-run equilibrium by changes in the trend growth rate of nominal money. 
Inflation may shift the aggregate production function downward, increase the Investment-1ncome ratio, and decrease labor 1 nput; ${ }^{31}$ real output, the real Interest rate, and the real exchange rate may be changed in either direction depending upon the relative importance of the various effects and upon parameters describing the economy. Furthermore, if increased money growth is accomplished through increased purchases of forelgn reserves this will tend to depreclate the real exchange rate. 32

My colleague James Lothian (1983) has recently made some calculations which demonstrate both the strength of the neutrality results and the relative unimportance of any deviations from superneutrality. In this work he analyzed for vartous variables the differences between thelr average growth rates for 1956-1973 and 1974-1980. Having obtalned data on these "growth shifts" for twenty OECD countries, Lothian showed that the growth shift in prices matched that in money while there was essentially no correlation between growth shifts

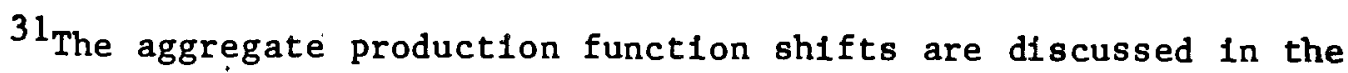
traditional literature on the costs of inflation. Tobin (1965) inftiated consideration of possible capltal deepening, and Friedman (1977) introduced the possibility that higher unemployment is caused by higher inflation rates.

32 The argument is that increased government flow demand for foreign securities will increase equilibrium net exports which can only be accomplished (under imperfect long-run goods substitutability) at a higher real exchange rate. Recent discussions of central-bank demand for forelgn reserves under floating exchange rates Include Heller and Khan (1978) and von Furstenberg (1982). However, Obstfeld's (1982a) results would imply here that equilibrium net exports would not increase if individuals viewed the government's holdings of forelgn securities as equivalent to their own. A full steady-state analysis requires consideration of the service-account effects of the government purchases (which would ultimately reduce net exports) discussed by Obstfeld (1981). Further, long-run price elasticlties may be much larger than the short-run elasticlties so that long-run perfect goods substitutability may be a close approximation to the truth. 
in output and money growth shifts. Figures 4 and 5 1llustrate these striking results. ${ }^{33}$ These results demonstrate that any shifts in levels of $y$ and $P$ due to fallure of superneutrality are negligible (when averaged over seven years) In comparison to efther random fluctuations in the growth rate of real output or to the changes in the growth of prices induced by the growth shift in money. Simllarly, Lothian finds that the growth shifts in either relative Inflation or relative money growth have an effect on the growth shift in the exchange rate which differs insignificantly from one. Having thus noted that neutrality and even superneutrality hold to an acceptable degree of approximation, we can concentrate on the independence of monetary policy and the reasons why its exercise might have a short-run 1mpact on real output and the real exchange rate even in the absence of any long-run effects.

Although frequently reacting in the same way to international events, those central banks which have not attempted to maintain pegs with other currencies after the breakdown of the Bretton-Woods system have certainly demonstrated their ability to pursue independent monetary policies. 34 The primary impact on real exchange rates of unexpected changes in monetary policy has been associated with the liquidity (or real-interest-rate) effect of these

${ }^{33}$ The lines are drawn through the sample means with the theoretical slopes (under neutrality and superneutrality) of 1 and 0 , respectively. Lothian's regression analysis indicates that we cannot reject at the $5 \%$ significance level either that the coefficient of $\Delta \Gamma \mathrm{M}$ is 0 in a linear regression explaining $\Delta \Gamma y$ or 1 in a similar regression for $\Delta \Gamma P$, where $\Delta \Gamma$ means "the growth shift $1 n "$ and where $y, M$, and $P$ are real GNP (or GDP), narrow money, and consumer prlces, respectively. He also ran U.S. dollar exchangerate $(E)$ equations of the forms $\Delta \Gamma E=a+b\left(\Delta \Gamma M-\Delta \Gamma M_{U S}\right)$,

$\Delta \Gamma E=a+b\left(\Delta \Gamma M-\Delta \Gamma M_{U S}\right)+c\left(\Delta \Gamma y-\Delta \Gamma y_{U S}\right)$, and $\Delta \Gamma E=a+b\left(\Delta \Gamma P-\Delta \Gamma P_{U S}\right)$; as reported In the text, In each case b differed from 1 insignificantly at the $5 \%$ level. ${ }^{34}$ See, for example, Darby and Lothian (1983) for our analysis of British monetary policy under Margaret Thatcher. 
F IGURE 4

Growth Shift in Consumer Prices vs. Growth Shift in Money

Twenty OECD Countries

$1956-1973,1974-1980$

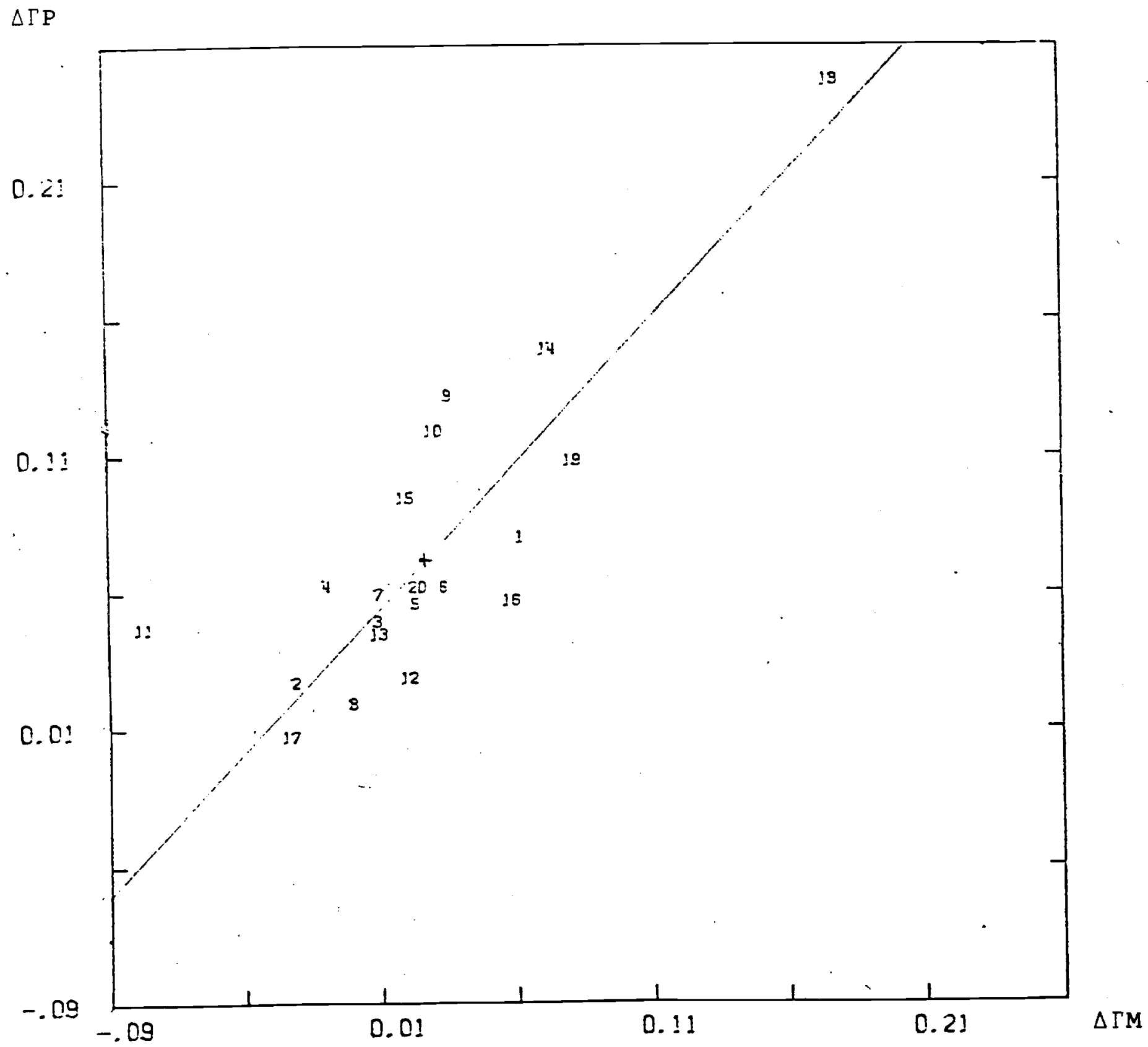

Source: Lothian (1983) 


\section{F IGURE 5}

Growth Shift in Real Output vs. Growth Shift in Money Twenty OECD Countries $1956-1973,1974-1980$

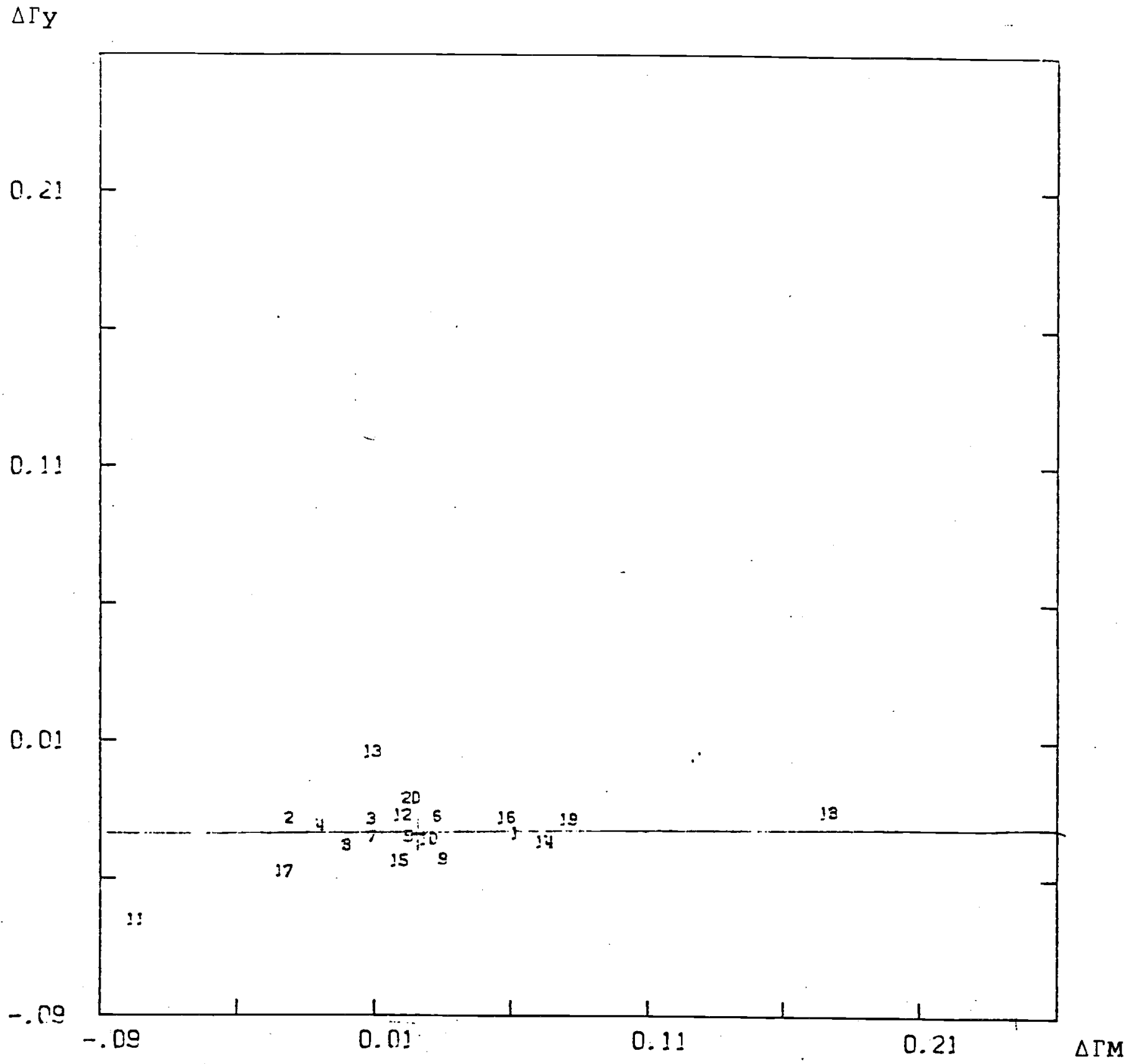

Source: Lothian (1983) 
monetary shocks. ${ }^{35}$ The basic 1dea is a simple one: An unexpected change in the interest rate at home relative to abroad w11 induce inciplent capital flows. If a positive money shock lowers the domestic interest rate, for example, a capltal outflow would be Induced, all other things equal. In order for this captial outflow to be stanched, the exchange rate must rise sufficiently that anticlpations of later decreases in this varlable reduce or eliminate the decrease in the Interest rate differentlal adjusted for expected depreclation. If assets were perfect substitutes internationally, the adjustment in expected depreciation would have to exactly offset the change in the interest rate. A smaller adjustment is required if assets are imperfectly substitutable internationally and some change in capital flows actually occurs because of elther contemporaneous adjustment in the trade balance or changes In central bank reserve purchases.

Suppose that Increased money growth were perfectly anticlpated so that equal contemporaneous changes occurred in the actual and expected inflation rate and growth rate of the nominal exchange rate. Then there would be no inftial jump in the exchange rate along the lines fust suggested. Thus it is seen that the movements in the nominal and real exchange rates associated with

35 A vast Ilsterature has blossomed from Dornbusch's seminal contribution (1976), but see also Dornbusch (1980, 1982). Horne (1983) reviews the emplrical research to date and concludes that "the evidence of the $1970 \mathrm{~s}$ supports the portfollo balance model" which is presented here. 
unexpected changes in monetary policy are due to movements in the real Interest rate. 36

This 1mpact effect of monetary pollcy on the real (and nominal) exchange rate mlght be quite large. For example, Goodhart and Temperton (1982) attribute nearly all of the 30 percent fluctuation in the British real exchange rate over 1979-1981 to monetary pol1cy. 37 This exchange-rate 1mpact adds a channel of Influence for monetary policy not present under pegged exchange rates: Unexpected decreases in money growth 1mmediately reduce the demand for traded goods and hence aggregate demand. 38 The 1mmediate effect on the trade balance of these movements in the real exchange rate is estimated to be close to n11.39 It is the lagged effects which apparentiy influence the adjustment process.

When we move from consideration of the Inftial impact of monetary shocks to the subsequent adjustment process, our emplrical base becomes weak, but some suggestive comments can be made. First, the initial movement of the real

36 If assets were perfect substitutes internationaliy, the home nominal (real) Interest rate would equal the forelgn nominal (real) Interest rate plus the growth rate of the nominal (real) exchange rate. Thus a pollcy which caused the domestic real interest rate to fall relative to the foreign real Interest rate by an average of $3 \%$ per annum for three years would induce an immediate $9 \%$ real depreclation so that the real exchange rate could be expected to decrease (1.e.., apprectate) by 3 percent per annum for the next three years. Isard (1982) has in particular argued that the long-run value of the real exchange rate is fixed by trade balance considerations (on which, see Section $V$ below) while Dooley and Isard (1981) extend the argument to apply qualitatively in an imperfect-substitution or portfolio-balance model.

37011 price movements (the prime alternative explanation) were found to have had a negligible impact.

${ }^{38}$ Under pegged exchange rates, prices of traded and nontraded goods move much more synchronously in the absence of a revaluation.

${ }^{39}$ That 1s, within the current quarter the changes in the quantities of exports and 1mports are approximately offset by the changes in thelr domesticcurrency prices. 
exchange rate is gradually eliminated over time, but whether this adjustment Is smooth or involves overshooting depends on the adjustment path of the real Interest rate. The trade balance increases over t1me in response to a positive monetary shock, but then the price advantage of an Increased (depreclated) real exchange rate is eliminated over t1me. Note, however, that the temporarily increased trade balance 1mplles private (or government) net accumulation of forelgn securitles in excess of what would otherwise be the case. Once this accumulation becomes 1mportant, it implies a lower domestic Interest rate relative to the expected-depreciation-adjusted forelgn interest rate. Unfortunately the implications of this asset accumulation are far from well understood, but apparently depend in part on whether they are ult1mately reversed for reasons discussed in Section $\mathrm{V}$ below. 40

Sterilized Intervention in the forelgn exchange market - a continuing central-bank exchange of forelgn for domestic securities - can be used to moderate the required inftial movement in the real exchange rate. Th1s would be attractive, for example, if the otherwise disproportionate share of the costs born by the traded goods sector would make an antilnflationary policy polit1cally unacceptable. 41 The same factors which permit a degree of Independence to monetary pollcy under pegged exchange rates permit the simultaneous pursult of monetary and exchange-rate goals under floating exchange rates; in each case the reserve movements must be accepted as the cost of the central bank's Influence on the second varlable. Again, the effect of these flows on the expectation that the operations will be abandoned

${ }^{40}$ See, however, the ploneering effort by Henderson (1980).

${ }^{41}$ I am unaware of any attempt to compare the relative costs of sterilized intervention with direct subsidies to traded-goods producers. 
and the exchange rate change which would ensue would 11mit the central bank's freedom to pursue the secondary goal.

In summary, floating the exchange rate eliminates the short-and long-run Iimits on monetary growth, but also changes the Impact of monetary policy by speeding and increasing the impact on the traded-goods sector. This difference can be ameliorated by sterilized intervention to some extent. But ultimately cholce of a pegged exchange rate is a decision to restrict monetary growth to a range - determined by the reserve country -- within which the traded-goods sector can be protected by sterilized intervention. Abandonment of that complete protection is the cost of monetary independence. 


\section{Some Rationa1-Expectations Considerations}

Thus far we have been concerned with the feasible set from which the central bank can select comblnations of money growth, reserve flows, and exchange rates and with the results of that cholce. Expectations have been left largely in the background except for the expected rate of depreclation. But much recent macroeconomic research has demonstrated the 1mportance of expectations in determining the point of departure relative to which we have been comparing the effects of unanticipated policy changes. This research cautions us that the short-run 1mpacts of the policles considered depend cruclally upon the unexpected nature of these pollcles. Therefore the shortrun 1mpacts on the real economy would not exist if the central bank systematically attempted to explo1t, say, the beneficent effects of accelerated money growth on the traded-goods sector under floating exchange rate system.

Some economists working in the strict rational-expectations tradition assoclated with Robert Lucas and Thomas Sargent have gone beyond these we11 known cautions agalnst attempts to explo1t effects assoclated with policy Innovations. In particular, they have attempted to analyze the variance of output Implied by simple models under alternative exchange-rate/monetarypollcy reglmes. 42 These authors show that an optimal portfollo of forelgn disturbances may reduce the varlance of output and thus stabllize the economy relative to a policy regime which more effectively insultates the economy from forelgn disturbances. Some authors emphasize the private sector's adjustment

42 See, for example, Sa1d1 (1980), Weber (1981), Flood and Mar1on (1982), Flood (1982), and Kimbrough (1983). 
In the output-inflation tradeoff as the regime changes while others emphasize potential informational content of exchange rate movements.

The rational-expectations models remain very simple and cannot yet provide any practical guidance to policymakers. They do raise the issue, however, of whether the relevant questions concern the feasibility and effect of a particular money growth under a particular exchange rate regime or the stochastic structure of the economy which would result from alternative rules for choosing monetary growth. 
V. Capital Flows, the Trade Balance, and the Real Exchange Rate 1n Long-Run Equ111br1um

The discussion so far has treated the trade balance as predetermined with capital flows and depreclation-adjusted interest rates adjusting to maintaln equilibrium. The concept of an autonomous trade balance has little appeal once we move beyond the Inftlal short perfod. Indeed the long-run equilibrium is better characterized by autonomous net capital outflows and passively adjusting trade balance and real exchange rate.

Th1s is seen most easily by noting that only one real exchange rate is consistent with a given trade balance in long-run equ1librlum. ${ }^{43}$ Therefore expected real depreciation is inconsistent with long-run equilibrium, and capital flows must be responding to actual differences in real interest rates. Suppose Japan has a high saving-1ncome ratio relative to the rest of the world and the Unfted States a relatively low one. If both economies always malntalned zero trade balances and capital flows, the real interest rate would become low in capital-rich Japan and h1gh in the U.S. 44 Instead capttal outflows and trade surpluses for Japan and capital inflows and trade deficlts for the U.S. have achleved a more efficient world distribution of the capltal stock. However, these flows will not cont1nue forever: As Japanese

${ }^{43}$ If goods are perfect substitutes internationally, an infinity of trade balances will be assoclated with the single equilibrium real exchange rate. If goods are imperfect substitutes internationally even in the long run, then h1gher (more depreclated) real exchange rates will be assoclated with higher trade balances. In a growlng economy, the trade balance is best measured as a rat1o to GNP.

${ }^{44}$ To the extent that Japan speclalizes in highly capital-1ntensive goods and the U.S. In less capital-intensive goods, this tendency is ameliorated. An alternative, complementary basis for net capital inflows to the U.S. is the political security of private investments there. 
wealth rises, its growth rate (saving/wealth) will fall unt1l it converges to the growth rate of output in the world economy. 45 Eventually, assuming this growth rate is less than the real return on capttal, Japan's forelgn Investment Income w1I exceed 1ts net forelgn Investments and the difference w111 finance - Indeed force - a trade defic1t. Throughout the adjustment process and in very long-run equilibrium, the excess saving in Japan (or saving shortage in the U.S.) determines the equilibrium net capital outflows and hence the trade balance and real exchange rate. Commerclal polfcy can only alter the composition of the trade balance by affecting relative delivered prices and hence apparent comparative advantage. 46

If then we adopt the view that in the long run national capital stocks and wealth will be unaffected by unexpected money growth, we must conclude as suggested in Section III - that the adjustment process to a monetary shock cannot be characterized by smooth adjustment. The abnormal capital flows Induced by inftial movements in the real exchange rate must ultimately be undone by offsetting movements. We conclude that it will be some time before a full understanding of the Intermediate effects of monetary shocks is achieved. 47

45 Japanese wealth was abnormally low in the early postwar perfod both because of wartime devastation and because of the rapid growth in Japanese human capital.

${ }^{46}$ It is curfous that U.S. labor unions would focus on the "Jobs lost" due to the excess of 1mports over exports rather than the corresponding gain in employment and real wages due to the capital inflows financed by the trade deficit.

${ }^{47}$ An exploratory effort integrating trade and capital flows in a full adjustment analysis is reported in Darby, Lothian, et al. (1983, Chapter 12 by Dan Lee). 


\section{Conclusions}

The Bretton Woods System afforded the major nonreserve central banks a range for 1ndependent monetary policy which was neither negliglble nor unlimited. The banks' resistance to accelerating Anerican inflation in the late 1960 s ultimately broke down and the resulting burst of inflation in the early 1970s led to the collapse of the Bretton Woods System. ${ }^{48}$ The ensuing decade of generalized floating among major currencles (or currency blocs) has presented some surprises and so engendered much theoretical and empirical research.

The work to date suggests that the major source of Instability in real exchange rates has been Instability in monetary pollcy. The Federal Reserve System has long been Infamous for accelerating money growth to reduce unemployment and then causing a recession to control the resultant Inflation. 49 The high Inflation legacy of the Bretton Woods System has left the other major central banks with a simflar dilemma and unfortunately simflar results. One aspect of the exercise of independent monetary policy is the major 1mpact on the traded-goods sector which is both quicker and stronger than that assoclated with the sorts of unexpected money growth which could occur under the Bretton Woods System.

\footnotetext{
48 A detalled discussion is provided by Darby and Lothian in Darby, Lothian, et al. (1983, Chapter 17).

${ }^{49}$ Whether this reflects a defect in the Federal Reserve System or in the American political system is not addressed here.
} 
REFERENCES

Bilson, John F. O., "Leading Indicators of Currency Devaluation," Columbia Journal of World Business, Winter 1979, pp. 62-76. , "The Speculative Efficiency Hypothesis," Journal of Business, July 1981, 54: 435-52.

Branson, William H., Financial Capital Flows in the U.S. Balance of Payments, Amsterdam: North-Holland Publishing Co., 1968. , "Monetary Pollcy and the New View of International

Capital Movements," Brookings Papers on Economic Activity, 1970 (2): $235-262$.

Connolly, Michael, and Taylor, Dean, "Exchange Rate Changes and

Neutralization: A Test of the Monetary Approach Applied to Developed and Developing Countries," Economica, August 1979, 46: 281-294. Cuddington, John T., "Currency Substitution, Capital Mobility, and Money Demand," Journal of International Money and Finance, August 1983, 2: in press.

Cumby, Robert E., and Obstfeld, Maurice, "A Note on Exchange-Rate Expectations and Nominal Interest Differentials: A Test of the Fisher Hypothesis," Journal of Finance, June 1981, 36: 697-703. , "International Interest-Rate and Price-Leve1 Linkages under Flexible Exchange Rates: A Review of Recent Evidence," in J. F. O. Bilson and R. C. Marston, eds., Exchange Rates: Theory and Practice, NBER Conference Report, Chicago: University of Chicago Press, 1983, in press.

Darby, Michael R., and Lothian, James R., "British Economic Pollcy under Margaret Thatcher: A Midterm Examination," Carnegie-Rochester Conference 
Series on Public Pollcy, Spring 1983, 18: In press.

Darby, Michael R., Lothlan, James R., Gandolf1, Arthur E., Schwartz, Anna J., and Stockman, Alan C., The International Transmission of Inflation, A National Bureau of Economic Research Monograph, ChIcago: University of Ch1cago Press, 1983. [1n press]

Dooley, Michael P., and Isard, Peter, "The Portfollo-Balance Model of Exchange Rates," International F1nance D1scussion Papers No. 141, Board of Governors of the Federal Reserve System, May 1979. , "Capital Controls, Political Risk, and

Deviations from Interest-Rate Parity," Journal of Political Economy, Apri1 1980, 88: $370-384$. Dornbusch, Rudiger, "Expectations and Exchange Rate Dynamics," Journal of Political Economy, December 1976, 84: 1161-1176. , Open Economy Macroeconomics, New York: Basic Books, Inc.,

1980. , "Flexible Exchange Rates and Interdependence," National

Bureau of Economic Research Working Paper No. 1035, November 1982. Fausten, Dietrich R., "The Humean Origin of the Contemporary Monetary Approach to the Balance of Payments," Quarterly Journal of Economics, November $1979,93: 655-673$.

Flood, Robert P., "Activist Pollcy in the Open Economy," American Economic Review, Papers and Proceedings, May 1982, 72: 51-55. , and Marion, Nancy Peregrim, "The Transmission of Disturbances under Alternative Exchange-Rate Regimes with Optimal Indexing," Quarterly Journal of Economics, February 1982, 97: 43-66. Frankel, Jeffrey A., "In Search of the Exchange Risk Premium: A Six-Currency Test Assuming Mean-Varlance Optimization," Journal of International Money 
and Finance, December 1982, 1: 255-274.

Friedman, Milton, "Nobel Lecture: Inflation and Unemployment," Journal of Political Economy, June 1977, 84: 451-72.

Geweke, John, and Felge, Edgar, "Some Jolnt Tests of the Efficiency of Markets for Forward Foreign Exchange," Review of Economics and Statistics, August $1979,61: \quad 334-341$.

Goodhart, C. A. E., and Temperton, P. V., "The U.K. Exchange Rate, 1979-81: A Test of the Overshooting Hypothes1s?," Bank of England, Xeroxed 1982. Hansen, Lars Peter, and Hodrick, Robert J., "Forward Exchange Rates as Optima1 Predictors of Future Spot Rates: An Econometric Analysis," Journal of Polftical Economy, October. 1980, 88: 829-853. , "R1sk Averse Speculation in the

Forward Forelgn Exchange Market: An Econometric Analysis of Linear Models," in J. Frenkel, ed., Exchange Rates and International

Macroeconomics, NBER Conference Report, Chicago: University of Chicago Press, 1982.

Harberger, Arnold C., and Edwards, Sebastian, "Lessons of Experience under

Fixed Exchange Rates," In M. Gersovitz, C. Diaz-Alejandro, G. Ranis, and M. R. Rosenzweig, eds., The Theory and Experience of Economic

Development: Essays in Honor of Sir W. Arthur Lewis, London: George

Allen and Unwin, 1982.

Heller, H. R., and Khan, M. S., "The Demand for International Reserves under Fixed and Floating Exchange Rates," International Monetary Fund Staff Papers, December 1978, 25: 623-649.

Henderson, Dale W., "The Dynamic Effects of Exchange Market Intervention Pollcy," in H. Frisch and G. Schwodiauer, eds., The Economics of Flexible Exchange Rates, supplement to Kredit und Kapital, 1980. 
Herring, Rlchard J., and Marston, Richard C., National Monetary Pollcles and International Financial Markets, Amsterdam: North-Holland Publishing Co., 1977.

H1111ard, Brian C., "Exchange Flows and the Gilt-Edged Securfty Market: A Causality Study," Bank of England, Discussion Paper No. 2, February 1979. Horne, Jocelyn, "The Asset Market Model of the Balance of Payments and the Exchange Rate: A Survey of Emplrical Evidence," Journal of International Money and Finance, August 1983, 2: In press. Isard, Peter, "How Far Can We Push the 'Law of One Price?'," American Economic Review, December 1977, 67: 942-948. , "An Accounting Framework and Some Issues for Modelling How Exchange Rates Respond to the News," International Finance Discussion Paper No. 200, Board of Governors of the Federal Reserve System, January 1982.

Kimbrough, Kent P., "The Information Content of the Exchange Rate and the Stability of the Real Output under Alternative Exchange-Rate Regimes," Journal of International Money and F1nance, Apr11 1983, 2: in press. Rravis, Irving B., and Llpsey, Robert E., "Export Prices and the Transmission of Inflation," American Economic Review, February 1977, 67: 155-163. , "Price Behavior in the Light of

Balance of Payments Theories," Journal of International Economics, May 1978, ㅇ: 193-246.

Krugman, Paul, "A Model of Balance-of-Payments Crises," Journal of Money, Credit, and Banking, August 1979, 11: 311-325. Laffer, Arthur B., "The Phenomenon of Worldwide Inflation: A Study in International Market Integration," in David I. Melselman and Arthur B. Laffer, eds., The Phenomenon of Worldwide Inflation, Washington: 
American Enterprise Institute for Public Policy Research, 1975. Laney, Leroy 0. , and Willett, Thomas D., "The International Liquidity

Explosion and Worldwide Inflation: The Evidence from Sterilization Coefficient Estimates," Journal of International Money and Finance, August 1982, 1: $141-152$.

Lothian, James R., "International Tests of the Neutrality of Money," Citibank, N.A., processed, April 1983.

Lucas, Robert E., Jr., "Econometric Policy Evaluation: A Critique," CarnegieRochester Conference Series on Public Policy, 1976, 1: 19-46. Obstfeld, Maurice, "Sterilization and the Offsetting Capital Movements: Evidence from West Germany, 1960-1970," National Bureau of Economic Research Working Paper No. 494, June 1980. , Macroeconomic Policy, Exchange-Rate Dynamics, and Optimal Asset Accumulation," Journal of Political Economy, December 1981, 89: $1142-1161$ , "The Capitalization of Income Streams and the Effects of

Open-Market Policy under Fixed Exchange Rates," Journal of Monetary Economics, January 1982, 9: 87-98. (1982a) , "Can We Sterilize? Theory and Evidence," American Economic Review, Papers and Proceedings, May 1982, 72: 45-50. (1982b) Richardson, J. David, "Some Empirical Evidence on Commodity Arbitrage and the Law of One Price," Journal of International Economics, May 1978, 8: 341351.

Saidi, Nasser H., "Fluctuating Exchange Rates and the International

Transmission of Economic Disturbances," Journal of Money, Credit, and Banking, November 1980,12 : 575-591.

Solnik, Bruno H., European Capital Markets: Towards a General Theory of 
International Investment, Lexington, Mass.: Lexington Books, 1973. Tobln, James, "Money and Economic Growth," Econometrica, October 1965, 33: $671-84$.

von Furstenberg, George M., "New Estimates of the Demand for Non-Gold Reserves under Floating Exchange Rates," Journal of International Money and F1nance, Apri1 1982, 1: 81-95.

Weber, Warren E., "Output Varlabll1ty under Monetary Pollcy and Exchange Rate Rules," Journal of Polittcal Economy, August 1981, 89: 733-751. Whitman, Marina v.n., "Global Monetarism and the Monetary Approach to the Balance of Payments," Brooklngs Papers on Economic Act1vity, 1975 (3): 491-536. 